$1-1-2017$

\title{
Transforming Societies after Violence: Conceptualizing and Contextualizing Transitional Justice in Africa
}

Jennifer Moore

University of New Mexico - School of Law, moore@law.unm.edu

Follow this and additional works at: https://digitalrepository.unm.edu/law_facbookdisplay

Part of the Law Commons

\section{Recommended Citation}

Moore, Jennifer. "Transforming Societies after Violence: Conceptualizing and Contextualizing Transitional Justice in Africa." Transitional Justice in Post-Conflict Societies in Africa (2017). https://digitalrepository.unm.edu/law_facbookdisplay/24

This Book Chapter is brought to you for free and open access by the School of Law at UNM Digital Repository. It has been accepted for inclusion in Faculty Book Display Case by an authorized administrator of UNM Digital Repository. For more information, please contact amywinter@unm.edu. 


\title{
Transforming Societies after Violence: \\ Conceptualizing and Contextualizing Transitional J ustice in Africa
}

\author{
Prof. J ennifer Moore \\ University of New Mexico School of Law \\ draft for SSRN publication
}

forthcoming chapter in: Transitional Justice in Post-Conflict Societies in Africa (J.R. Stormes SJ, E.O.

Opongo SJ, K. Wansamo SJ, and P. Knox SJ, eds., ACORD and HIPSIR ${ }^{1}$, 2015)

\section{$\underline{\text { Introduction }}$}

The term "transitional justice" is common usage these days in international, human rights, and diplomatic circles. Depending on the audience, it is a familiar term of art or an empty catchphrase, the cure for what ails us or the subject of dispute, at times weighty in its self-importance or apologetic in its impotence. At its best transitional justice is a concept that is both idealistically ambitious and responsibly pragmatic. But before getting to its application, we should define it more precisely. For like justice itself, transitional justice can be understood in myriad ways.

To many, transitional justice is a mechanism of judgment, administered by judicial bodies through penal sanctions imposed on the perpetrators of war crimes and outrages against the civilian population, carried out in the context of a protracted civil conflict. For others it is a quality of mercy, expressed through official hearings and communal ceremonies in which perpetrators and victim-survivors of atrocities are reconciled through truth-telling, apology, and forgiveness. And for still others it is a commitment to change - socio-economic, cultural, and political - through programs of reparation and social reform, enhanced economic opportunity, political pluralism, and gender equality, all seeking to alleviate the root causes of military violence and

\footnotetext{
${ }^{11}$ ACORD is the Agency for Cooperation and Research in Development (Nairobi) and HIPSIR is the Hekima Institute of Peace Studies and International Relations, Catholic University of Eastern Africa (Nairobi)
} 
repression. In practice, transitional justice can encompass all this and more, offering a broad spectrum of tools for men and women in post-war societies to test and adapt to their own purposes as they emerge from protracted armed conflict and seek enduring social transformation. ${ }^{2}$

Transitional justice might be conceived as a braid with three strands: criminal justice, historical justice, and social justice. ${ }^{3}$ Criminal justice seeks individual accountability through war crimes prosecutions of serious offenders. Historical justice entails truth-telling endeavors at the national and local levels to help survivors collectively reckon with the past and build a deeper capacity for co-existence. Social justice promotes structural reforms to alleviate the material inequalities that generate conflict. The three-stranded braid is not a perfect metaphor, but it does evoke the complex textures and inter-connectedness of the various facets of transitional justice.

But if we conceptualize transitional justice by identifying its retributive, reconciliative, and redistributive strands, we also need to contextualize post-conflict transition by considering how the visionary concepts are implemented on the ground in individual countries emerging from prolonged civil strife. Even if there is a fair amount of agreement in the abstract, the specific applications of the theory of transitional

\footnotetext{
${ }^{2}$ See generally Jennifer Moore, Humanitarian Law in Action within Africa (Oxford University Press, 2012), Chapter 6, at 177-207. See generally United Nations, "Guidance Note of the Secretary General: United Nations Approach to Transitional Justice," March 2010, available at www.unrol.org/files/TJ Guidance Note March 2010FINAL.pdf. See also International Center for Transitional Justice, "What is Transitional Justice," available at http://www.ictj.org/about/transitional-justicehttp://www.ictj.org/about/transitional-justice.

${ }^{3}$ See Moore, op. cit., at 324.
} 
justice vary quite dramatically in particular settings. ${ }^{4}$ Studying transitional justice in individual countries helps illuminate the ways in which accountability mechanisms, truth-telling, and community welfare programs can be integrated in meaningful ways. It is perhaps too easy to posit that punishing offenders, reconciling adversaries, and alleviating poverty and gender inequality are essential ingredients of durable peacebuilding. The varying degrees of emphasis on the three components of justice and the progress in achieving them are worthy of analysis and critique in specific human contexts. Historical, cultural and geopolitical context matters.

\section{A Note on the Country Studies}

This paper draws from the experiences of three African countries over the five to ten years since the warring parties in each country signed formal peace agreements. The focus on these countries does not imply that the African continent is uniquely in need of transformation or singularly successful in achieving it. Rather, a regional comparative study allows us to look at post-conflict transition on the ground, to search for the "angels" as well as the "devil" in the details. Uganda, Sierra Leone, and Burundi are quite distinct in their colonial and post-colonial experiences, their ethnopolitical heritages and their legal and governmental systems. At the same time, all three countries experienced more than a decade of armed conflict characterized by widespread attacks on civilians, and they share a rhetorical and operational

\footnotetext{
${ }^{4}$ See generally George Wachira with Prisca Kamungi and Kalie Sillah, Stretching the Truth: The Uncertain Promise of TRCs in Africa's Transitional Justice (Nairobi Peace Initiative-Africa and West African Network for Peacebuilding, 2014). Wachira et al argue for a context-specific approach to the implementation of transitional justice in individual countries. Ibid. at 143.
} 
commitment to transitional justice, particularly in the long term. For all these reasons, there is much to be gained by comparing and contrasting post-conflict transformation in the three settings.

\section{A Note on the Civil Society Organizations: RLP, Fambul Tok and CENAP}

Crucial to the specific process of social transformation in a given country are the civil society organizations working at the grassroots level in communities impacted by years of armed conflict, death, destruction, and displacement. These groups serve as the catalysts for legal, cultural, and socio-economic change, fashioning mechanisms of social transformation by adapting and combining the criminal, historical, and social strands of justice in a way that is responsive to their particular contexts. In order to illustrate the importance of civil society in animating transitional justice at the granular level, this article will spotlight the work of a non-governmental organization working in each country. The Refugee Law Project in Uganda, Fambul Tok in Sierra Leone, and le Centre d'Alerte et Prévention de Conflit in Burundi are three dynamic organizations dedicated to post-conflict transition in their respective countries.

The Refugee Law Project (RLP), ${ }^{5}$ based at Makerere University's School of Law, offers a powerful critique of Uganda's disproportionate reliance on criminal justice as a mechanism for post-conflict transformation, and its to-date exclusive prosecution of non-state actors. RLP calls for more even-handed prosecutions of civil war offenders,

\footnotetext{
${ }^{5}$ Information about the mission and activities of Uganda's Refugee Law Project is available at http://www.refugeelawproject.org/our-work/conflict,-transitional-justice-governance.html.
} 
on the one hand, and for greater attention to restorative justice, on the other, through the restoration of collective memory as well as the rebuilding of healthy communities.

Contrastingly, Sierra Leone in recent years hosted both a Special Court and a Truth and Reconciliation Commission. Fambul Tok, ${ }^{6}$ under the leadership of J ohn Caulker, was founded to pick up where those two institutions left off, to promote district and village-level reconciliation and collaborative development, complementing the important but limited accomplishments of the national mechanisms.

Finally, le Centre d'Alerte et Prévention de Conflit (CENAP), ${ }^{7}$ under the helm of Charles Ndayiziga, was founded to create a national dialogue on transitional justice in Burundi. CENAP began its work in what some characterized as a "formal justice vacuum," given the failure to establish a Burundian war crimes tribunal and protracted delays in the creation of Burundi's Truth and Reconciliation Commission. ${ }^{8}$ Against this backdrop, CENAP continues to support the efforts of Burundians to construct an inclusive and trans-ethnic national identity, to promote peaceful and democratic

\footnotetext{
${ }^{6}$ A profile of Sierra Leonean John Caulker and his work with Fambul Tok is available at http://www.fambultok.org/about-us/staff-profiles.

${ }^{7}$ A synopsis of the Burundian National Radio's 2010 coverage of the early work of CENAP can be found at http://www.rtnb.bi/index.php?option=com content\&id=218:le-centre-dalerte-et-de-prevention-des-conflitspresente-un-rapport-centre-sur-les-preoccupations-de-la-population.

${ }^{8}$ Burundi's TRC was formally constituted in December 2014 by the Burundian Parliament. See "Burundi: Truth Commission elected amid opposition boycott," Hirondelle News Agency, December 5, 2014, available at http://allafrica.com/stories/201412050134.html/. On December 1, 2014, the eleven TRC members were elected by the Parliament from a list of 725 candidates. The election was held pursuant to legislation passed earlier in 2014, which mandated the TRC to investigate mass crimes occurring between 1962 and 2008, including but not limited to the civil war period (1993-2006). The TRC is also charged with identifying mass graves, proposing reparations, and promoting reconciliation. The eleven members of the TRC include six ethnic Hutu, four ethnic Tutsi, and 1 ethnic Twa; four are women, and seven are men. In part because the TRC statute did not call for criminal prosecutions, the opposition boycotted the December vote, charging the ruling FNDD-CDD with attempting to immunize itself from accountability for civil war atrocities. Id.
} 
elections, to empower youth, and to demand accountability throughout all sectors of government and civil society.

Analytic Roadmap

The first section of this paper analyses three facets of transitional justice - the criminal-retributive, the historical-reconciliative, and the social-redistributive - and identifies some of the synergies and tensions among them. The second section shines a spotlight on the post-independence, conflict, and post-conflict histories of Uganda, Sierra Leone, and Burundi, generally characterizing their distinct approaches to transitional justice, and the differing degrees of attention they devote to the various strands of justice. For each of the three countries, this section also points to the work of one of the three organizations mentioned above, and its approach to post-conflict transition in that country.

The final section of the paper takes a sober look at the current capacity of transitional justice as a force for social change, given the reality of entrenched poverty and gender inequality in all three post-conflict societies. This section ends with an assessment of the efforts of the individual civil society organizations to address human insecurity, including the physical and structural forms of violence that women in each country confront every day. In learning from the experiences of these three conflictemergent countries, and considering the contributions of civil society organizations in each, we may better frame the unfinished business of transitional justice as a transformative movement that meaningfully impacts the quality of life for people living in countries throughout the world. 
I. The Three Strands of Transitional J ustice: Criminal, Historical, and Social J ustice

A. Criminal J ustice

For societies emerging from the cataclysmic violence of protracted civil war, "criminal justice" is typically the demand for punishment of those most responsible for armed attacks on the civilian population. This punitive component of transitional justice entails trials before regularly constituted or temporary criminal courts, created through national legislation or by treaty. Individuals suspected of war crimes and crimes against humanity are charged with specific offences, defined by national legislation and/or international law. Defendants must be accorded due process, including the presumption of innocence and the opportunity to appeal, before they are acquitted or convicted of enumerated offences. Convicted war criminals serve their terms of imprisonment either in the home country or abroad.

In Uganda, five top deputies of the Lord's Resistance Army (LRA) have been indicted by the International Criminal Court, to face charges of war crimes and crimes against humanity. Only Dominic Ongwen, who surrendered to U.S. forces in the Central African Republic in January of 2015, has yet been apprehended. ${ }^{9}$ In Sierra Leone, a Special Court was established pursuant to the Lomé Peace Accords, which convicted nine individuals of various warring parties for war crimes and crimes against humanity

\footnotetext{
${ }^{9}$ See Cyanne E. Loyle, "Amnesty, the ICC and Complications with the Dominic Ongwen Case," March 23, 2015, a guest blog post on Political Violence at A Glance: Expert Analysis on Violence and its Alternatives, available at http://politicalviolenceataglance.org/2015/03/23/amnesty-the-icc-and-complications-with-the-dominic-ongwencase/.
} 
in that country's civil war. Burundi, in contrast, has conducted no war crimes prosecutions to date since the Arusha Peace Accords were signed in 2000.

In point of fact, criminal justice measures do not and cannot get at all the perpetrators of war-linked violence, nor do such procedures give many victim-survivors the chance to be heard, and nor do they typically result in significant reparations for victims and their communities. Nevertheless, many would argue that criminal convictions of even a representative sample of the perpetrators of war crimes play an essential role in "de-normalizing" violence. Furthermore, criminal justice measures reaffirm the values of human dignity and humane treatment, and vindicate the principles of distinction and proportionality. Finally, criminal justice measures can sometimes work in concert with the other strands of transitional justice, in both the reconciliative and redistributive realms.

B. Historical justice

In contrast to the individual accountability of criminal justice, "historical justice" contemplates a collective process for reckoning with the causes, conduct, and consequences of the war. Wachira, Kamungi and Sillah stress that while war crimes tribunals may be of great utility in situations where state actors were the main perpetrators of atrocities, ${ }^{10}$ some armed conflicts are different. State repression is often top-down, whereas in civil wars the violence tends to be horizontal as well as vertical. Wachira et al argue that reconciliative measures are likely to be more fruitful

\footnotetext{
${ }^{10}$ Wachira et al, op. cit., at 39.
} 
than retributive mechanisms where there was significant "popular agency" in crimes against humanity. ${ }^{11}$

The familiar institutional framework for historical justice is the national Truth and Reconciliation Commission (TRC), in which post-conflict countries draw on, adapt or reshape the model of South Africa's TRC in individual national settings. ${ }^{12}$ Ideally, and in broad strokes, truth and reconciliation procedures give victims the chance to tell their stories and to confront their offenders, while giving perpetrators the opportunity to acknowledge their crimes, sometimes but not always in exchange for amnesty. Sierra Leone created a TRC in 2002 to operate alongside its Special Court. In contrast, calls for a Ugandan TRC were still at the rhetorical stages in early $2015 ;{ }^{13}$ and it took almost a decade after the civil war for Burundi's TRC members to be installed in late $2014 .{ }^{14}$

The "justice" in historical justice is not exclusively between individual victims and perpetrators of war crimes, and rather reverberates across broad sectors of a society grappling with the legacy of protracted civil strife. Rather than punishing offenders, historical justice seeks to set the record straight, to name the wrongs that occurred, and, ultimately, to restore relationships between individuals and polarized groups within society. In chronicling the war, truth-tellers record its specific crimes, specify particular localities and events, and identify responsible individuals and institutions, above all

\footnotetext{
${ }^{11}$ Ibid. at $41-43$.

${ }^{12}$ Wachira et al critique the wholesale ("cookie cutter") application of a "universalized" model of the Truth and Reconciliation Commission to African countries and argue instead for a more adaptive approach. Ibid at 143.

${ }^{13}$ See Marvin Kirunda, “UPC calls for reconciliation commission," The Monitor [Uganda], February 19, 2015, available at http://www.monitor.co.ug/News/National/UPC--reconciliation--commission/-/688334/2628158/Lofagpjz/-/index.html.

${ }^{14}$ Supra note 7.
} 
honoring the individual people who were attacked, killed, raped, wounded, or displaced. Participants in the reconciliative process, having looked backward, then look forward, galvanized by their collective awareness that the new society they seek will be built largely by people who were not victims or perpetrators, but both.

Historical justice is sometimes seen as working at cross-purposes with criminal justice, as if the two were diametrically opposed, or even that historical justice is no justice at all, but a disgraceful outcome in the grand contest of "peace vs. justice." According to this hackneyed binary, the reconciliation that can come from truth-telling ceremonies sugar-coats individual penal responsibility, and hence defers and denies the fullest measure of "justice." This article makes a different claim, resisting the tendency to conflate justice into its mere penal forms. Such a reduction impoverishes our understanding of transitional justice and weakens its transformative power. While historical justice may lack the explicit retributive character of criminal justice, the two share certain essential qualities, among these the notion of consequences. Truth-telling delivers its own measure of accountability, facilitating intense personal interactions between individuals, and encouraging participants to be responsive to one another and to commit to respectful coexistence and collective action in the future.

Some participants in reconciliation activities affirm that the sincere exchange of apology and forgiveness, particularly within a local community, involves an upending of the prior power relationship between victim and offender and thus delivers a more powerful form of accountability than that provided by the more formalized procedures of trial and punishment, which typically involve the removal of the convicted person 
from his or her community. ${ }^{15}$ In contrast, when the village-level truth and reconciliation ceremony is over, victim and offender may have no option but to continue to live together as neighbors, ideally in a renewed relationship. As one Ugandan explains, forgiveness lets the wrongdoer "feel the shame. . . . You are free, but feel the weight of what you've done." 16

Wachira et al emphasize that reconciliation is a long process that only begins with formal hearings and cleansing ceremonies. As important as the cathartic interactions of victims and perpetrators are the issuance of TRC recommendations and the painstaking implementation of needed structural and institutional reforms. ${ }^{17}$

A shortcoming of the criminal and historical justice approaches to post-conflict transition is that both are limited in their ability to address the socioeconomic conditions and inequalities that give rise to violence and war. Social justice picks up the thread here.

C. Social justice

"Social justice" is typically the thinnest strand of transitional justice, when it should be the thickest, given that the taproots of violence so often spring from conditions of abject poverty and social marginalization. Gender inequality itself is associated with low levels of material security and high levels of violence. Without care,

\footnotetext{
${ }^{15}$ See generally Desmond Tutu, No Future Without Forgiveness (Doubleday, 1999).

${ }^{16}$ Hovil \& Lomo, “Whose Justice? Perceptions of Uganda's Amnesty Act 2000: The Potential for Conflict Resolution and Long-Term Reconciliation" (Refugee Law Project Working Paper No. 15, Feb. 2005) at 27 (citing interview with cultural leader, Gulu Town, 16 November 2004), available at http://www.refugeelawproject.org/resources/working-papers.html.

${ }^{17}$ Wachira et al, op. cit., at 227-29.
} 
entrenched and compounding social inequality undermines the progress of transitional justice in a conflict-emergent society, threatening to unravel the whole social fabric. As addressed in Section III below, government and civil society actors in Uganda, Sierra Leone, and Burundi increasingly acknowledge the necessity of social development, poverty alleviation, and gender empowerment for long-term stability in each country.

The social dimension of justice is vast, spanning a spectrum that includes better health care delivery, including reproductive, maternal, and preventive services; secure food supplies, water sources, and agricultural systems; strong public schools and postsecondary institutions; and enhanced training, employment, and income-generating opportunities. Collectively, the radical reforms necessary to realize some significant measure of social justice serve as "structural reparations" for the crimes suffered by individuals and communities. These institutionalized reparations are distinct from, although they may complement, monetary or programmatic reparations that individual victims of war crimes receive pursuant to criminal trials or truth commissions and ceremonies.

In contrast to the individual-penal accountability of criminal justice and the communal-relational accountability of historical justice, social justice involves yet another expression of accountability. It lies in the society's commitment to respect the human dignity of all its members, by fulfilling their basic material needs, defending their political agency, and promoting social equality. This kind of accountability builds and strengthens a healthy body politic, a vital economic system, and a tightly knit social fabric. 
II. The Three-Stranded Braid of Transitional J ustice in Uganda, Burundi, and Sierra Leone

The criminal, historical and social threads of justice are interwoven in the fabric of transitional justice. While all three strands share the component of accountability, they can fray as well as reinforce one another. Individual countries struggle with notions of transitional justice and the process is seldom linear or smooth. In Uganda, the criminal justice strand has dominated, certainly, but even war crimes prosecutions have been fraught with tensions and charges of partiality, one-sidedness, and victors' justice. In Sierra Leone, the criminal and historical justice institutions have been remarkably although imperfectly integrated, but both have exposed deeper problems of social inequality, entrenched poverty, and enduring violence. In Burundi, a growing commitment to historical justice in the form of national reconciliation between ethnic communities must confront ongoing corruption and political infighting within the largest ethnic community and the stark reality of social insecurity for the vast majority of the population. A deeper exploration of the experiences of these three countries will further illuminate the tensions and synergies between the various strands of transitional justice in societies emerging from conflict.

A. Criminal Prosecutions in Uganda and the Limits of Retributive J ustice Uganda, a British Protectorate until 1962, has been led since the 1980s by President Yoweri Museveni, now in his fourth term as democratically elected head of state. For much of his tenure in office, Museveni's Ugandan People's Defense Forces 
(UPDF) battled rebels of the Lord's Resistance Army (LRA) in the impoverished region of Northern Uganda. The LRA, headed by J oseph Kony, fueled its movement with powerful ethno-nationalist and spiritualist appeals to the Acholi people of Northern Uganda, and yet its insurgency was characterized by brutal attacks on Acholi communities. The twenty-year plus civil war was characterized by LRA atrocities as well as the forced expulsion and encampment of upwards of 2 million internally displaced persons (IDPs) by UPDF government troops. ${ }^{18}$ Of the 100,000 or more killed during the war, up to $90 \%$ are believed to have died due to hunger and sickness related to their conditions of life as IDPs and the remaining $10 \%$ at the hands of the LRA. ${ }^{19}$ In 2006, the Juba Peace Accords were promulgated and Uganda's post-conflict transition began.

In 2004, President Museveni referred the case of Northern Uganda to the International Criminal Court (ICC), seeking the Court's investigation of LRA crimes. While the ICC Prosecutor has discretion to issue indictments against all parties to the conflict, in fact there have been no indictments against state agents or members of the UPDF, despite evidence of child recruitment and attacks on civilian targets by government troops, as well as the forced displacement policy itself, and the subjection of the civilian population to inhumane conditions of life in IDP settlements. ${ }^{20}$ Some

\footnotetext{
${ }^{18}$ See generally Moore, op. cit., at Chapter 7, "Beyond Juba in Uganda: Reconciling Restorative and Retributive Justice," pp. 210-40.

${ }^{19}$ Amy Ross and Chandra Lehka Siram, "Catch-22 in Uganda: the LRA, the ICC and the Peace Process" (JURIST Legal News \& Research, University of Pittsburgh School of Law, July 17, 2006) at para. 10.

${ }^{20}$ In Uganda's petition to the ICC, the government asked the ICC to indict exclusively LRA militants. While the ICC Prosecutor's office refused to so limit the scope of future indictments in the Uganda case, there have in fact been no charges brought against UPDF fighters or other state actors. See generally, Moore, op. cit., at pp. 134-36.
} 
have argued that Museveni has attempted to do in the courtroom what he could not do on the battlefield, namely to defeat the LRA. ${ }^{21}$

Although J oseph Kony and three of the four other indicted leaders of the rebel movement remain at large, by 2011 LRA fighters had largely withdrawn from Northern Uganda. The LRA militancy continues in neighboring countries, with forced recruiting of children, and sporadic and lethal attacks on civilian communities in the Central African Republic, the Democratic Republic of the Congo, and the Darfur region of Sudan. Uganda's official approach to the post-conflict process has been to emphasize the criminal justice strand of transitional justice. Alongside international criminal prosecutions in the ICC, domestic war crimes prosecutions are feasible pursuant to the War Crimes Act, enacted by the Ugandan Parliament in 2010. The Act created a new International Crimes Division (ICD) in the Ugandan High Court. To date there has been one war crimes trial in the ICD, of LRA militant Thomas Kwoyelo. ${ }^{22}$

The Government of Uganda's path toward transitional justice has been found wanting by civil society organizations such as the Refugee Law Project for its focus on the criminal-retributive dimension of justice at the expense of historical-restorative mechanisms. A second critique has been leveled at both the ICC and the Ugandan

\footnotetext{
${ }^{21}$ William Schabas, Prosecutorial Discretion v. Judicial Activism at the International Criminal Court, 6 J. INT'L. CRIM. JUST. 731,552 (Sept. 2008).

22 "Uganda: War crimes trial may affect LRA defections - analysts," IRIN (a service of the United Nations Office for the Coordination of Humanitarian Affairs), July 29, 2011, http://www.irinnews.org/report/93377/uganda-warcrimes-trial-may-affect-Ira-defections-analysts.

Before the special chamber determined Kwoyelo's guilt or innocence on the substantive charges, he filed a certificate of relief from prosecution pursuant to the Amnesty Act, and a lower court granted him amnesty in 2011. The government has appealed that ruling and the case is still pending. Oroma Gladys, "Could Uganda Prosecute Joseph Kony?" The Institute for War and Peace Reporting, 23 January 2014, http://iwpr.net/reportnews/could-uganda-prosecute-joseph-kony.
} 
criminal justice system for allowing war crimes prosecutions to become politicized, given the so far total failure of accountability for state actors in Uganda, particularly members of the UPDF. Current initiatives being spearheaded by the RLP will be further addressed in Part III below.

B. After the Special Court and the TRC: Bringing Reconciliation Home in Sierra Leone Freetown, the capital of Sierra Leone, was founded in the late $18^{\text {th }}$ century by freed African slaves including those who had fought on the side of the British in the American War of Independence. The descendants of those freedmen and women are represented within the $\mathrm{Krio}^{23}$ ethnic group, and have intermarried with Sierra Leone's indigenous ethnic communities, including the Mende, the Temne, the Limba and the Mandingo. Sierra Leone subsequently became a British colony, was converted into a British Protectorate at the end of the $19^{\text {th }}$ century, and attained its independence from Great Britain in 1961.

While there has been some historical tension between the two largest tribal communities in Sierra Leone, the Temne and the Mende, the greater political fault line has corresponded to the development gap between what were formally referred to as the Freetown Colony and the up-country Protectorate. ${ }^{24}$ The alienation between the rural popular masses and the metropolitan political and economic elites would come to a violent head in the armed militancy of the Revolutionary United Front (RUF), which

\footnotetext{
${ }^{23}$ Krio is also a language, spoken by all Sierra Leoneans, whose linguistic heritage includes the languages of all the freed slaves who settled in Freetown, and English, intermixed with the indigenous languages of Sierra Leone.

${ }^{24}$ See Jimmy D. Kandeh, Politicization of Ethnic Identities in Sierra Leone, AFRICAN STUDIES REV., Vol. 35, No. 1 (April 1992), 81, 83.
} 
launched Sierra Leone's Rebel War in 1991. A few years into the conflict, the RUF descended into a kind of "entrepreneurial insurgency" - a militarized mercantile struggle for territory, arms, and control of mineral concessions. ${ }^{25}$ The conflict endured for a decade, until the official end of hostilities in $2002 .^{26}$

Sierra Leone's conflict morphed from an initially two-sided contest between the RUF and Sierra Leone's armed forces into a complex war between the RUF, the Armed Forces Defense Council (AFDC), the Civil Defense Forces (CDF) and ECOMOG, the peacekeeping force of the Economic Community of West African States (ECOWAS). The Lomé Accords were signed in 1999. By 2002, when hostilities had ended, RUF, AFDC, and CDF soldier-rebels had all engaged in atrocities against civilians. The war had affected every region of the country, including the capital, where in a single week in 2009, 6000 people were killed. Overall 50,000 civilians are believed to have been killed, as many as 10,000 children forcibly recruited, and countless numbers of women subjected to sexual violence. According to one report, up to half of all women who encountered RUF rebels during the war were sexually assaulted or raped. ${ }^{27}$

Sierra Leone's Truth and Reconciliation Commission (TRC), in its Final Report of 2004, assigned predominant responsibility for war atrocities to the RUF, particularly

\footnotetext{
${ }^{25}$ See Moore, op. cit., at 57-58, citing Joseph Opala's use of the term "competitive banditry," in "What the West Failed to See in Sierra Leone," Wash. Post, at B2, May 14, 2000.

${ }^{26}$ See generally Moore, op. cit., at Chapter 8, "After Lomé in Sierra Leone: The Special Court and National Reconciliation," pp. 241-82.

${ }^{27}$ Beth Dougherty, Right-sizing international criminal justice: the hybrid experiment at the Special Court for Sierra Leone, INT'L AFF. 80, 2 (2004), 311, 315, citing Physicians for Human Rights, War-Related Sexual Violence in Sierra Leone: A Population-Based Assessment (2002).
} 
child recruitment and forced drugging of child combatants. Nevertheless, the TRC concluded that criminal responsibility was widely shared, with special mention of the AFRC's practice of amputations, and the CDF's use of physical and psychological torture as a means of initiating new fighters. ${ }^{28}$ A nuanced historical treatment of the causes, military strategy, and ideological motivations behind Sierra Leone's civil war is provided by the TRC's Final Report, some thousands of pages long. ${ }^{29}$

By 2000 , and the final years of the civil war, Sierra Leone began to blaze a twolane path toward transitional justice, despite the strong amnesty provisions in the 1990 Lomé Accords. In addition to the TRC, envisioned in the Lomé instruments, Sierra Leone entered into a treaty with the United Nations to establish a Special Court, in order to prosecute those "who bear the greatest responsibility" for war crimes and crimes against humanity. ${ }^{30}$

The decision to undertake criminal-retributive and historical-reconciliative mechanisms simultaneously, through national institutions, makes Sierra Leone unique among the three countries profiled in this article. Former TRC Commissioner William Schabas' reference to "the conjoined twins of transitional justice" ${ }^{31}$ is evocative. While

\footnotetext{
${ }^{28}$ See Final Report of the Truth and Reconciliation Commission (TRC Final Report) (C) 2004, Sierra Leone Truth and Reconciliation Commission, Executive Summary, Chapter 2, "Primary Findings," paras. 33, 34 and 35 (found on p. 22 of the pdf file).

${ }^{29}$ See, especially, TRC Final Report, op. cit., paras. 13, 14 and 15.

${ }^{30}$ See Statute of the Special Court for Sierra Leone, available at http://legal.un.org/avl/ha/scsl/scsl.html, art. 1. See also Report of the Secretary General on the establishment of a Special Court for Sierra Leone (New York: United Nations, Oct. 4, 2000), UN Doc. S/2000/915, para. 26(c).

${ }^{31}$ See generally Schabas, "The Conjoined Twins of Transitional Justice? The Sierra Leone Truth and Reconciliation Commission and the Special Court," J. Crim. Justice 2 (2004).
} 
some have stressed the disadvantages of this pairing ${ }^{32}$ Sierra Leone's adoption of two national bodies devoted to transitional justice has also reverberated in positive ways.

Building upon the explicit criminal justice character of the Special Court, the TRC was created to promote historical justice. But it also delivered a measure of social justice, by demanding institutional and structural change. In its Final Report, the TRC calls for individual reparations, particularly access to free health care, and primary and secondary educational opportunities for war amputees, other war survivors, and their families. Further, the TRC recommends structural reparations, including certain mandatory legislative reforms, such as the abolition of prolonged detention without charge, and the outlawing of "corporal punishment against children, whether this be in schools or the home." Regarding gender-related violence, the TRC Final Report denounces "a culture of impunity in respect of crimes of a sexual nature," and "recommends that laws that link the prosecution of sexual offences to the moral character of a complainant should be repealed. This is an imperative recommendation." ${ }^{33}$

The TRC and the Special Court have been critiqued as well as praised by civil society. A particular concern was the limited impact of these national structures on individual lives and relationships in rural localities. Even the TRC hearings were limited to Freetown and the district seats. Thus Fambul Tok, which means "family talk" in Krio,

\footnotetext{
32 According to Joseph Sesay of Sierra Leone's Centre for Accountability and the Rule of Law, the Court may have dampened some perpetrators' willingness to testify before the TRC for fear of criminal prosecution despite formal procedural protections to the contrary. See, Moore, op. cit., at 257 and n. 94, citing electronic correspondence with Sesay.

${ }^{33}$ See TRC Final Report, op. cit., Chapter 2, "Recommendations," para. 5.
} 
was created to bring the process of reconciliation into more intimate community settings. The organization builds upon traditional conflict resolution practices, whereby community members air their grievances, often mediated by elders.

Fambul Tok developed a two-stage methodology, first by conducting outreach at the chiefdom level, whereby youth activists ask locals to define what reconciliation means to them, and how to achieve it; and second by helping to organize victimoffender reconciliation ceremonies at the village level, based on community input and volunteer participation. Fambul Tok also helps to organize collective agricultural and other rural development projects in its affiliate communities to enhance the quality of daily life for ordinary Sierra Leoneans. In this sense, the work of Fambul Tok emphasizes both the historical-reconciliative and social-redistributive strands of postconflict transition, suggesting that the two are intertwined. While Fambul Tok is less focused on the criminal-retributive strand of transitional justice, the personal accountability component of criminal justice is present in the intense interpersonal reckonings that often arise in the context of village-level cleansing ceremonies. New initiatives being undertaken by Fambul Tok will be further explored in Section III.

C. Calls for Collective Memory, Transnational Identity and Clean Politics in Burundi Burundi won its independence in 1962 from Belgium, after a colonial period characterized by an apartheid-like system in which the two major ethnic communities, Hutu and Tutsi, were racialized and subjected to differential treatment in terms of access to educational opportunities and employment in a system that favored the Tutsi. 
Over the next thirty years, Burundi experienced a series of syncopated transitions in governmental leadership, in an overall pattern in which Hutu leaders were pushed out or assassinated, Hutu militant ultranationalists repressed the Tutsi community, and Tutsi members of the Burundian Armed Forces as well as Tutsi militant ultranationalists in turn repressed the Hutu community.

In 1972, a Hutu ultranationalist party carried out explicitly racist attacks on Tutsi people, which led to reprisal attacks on Hutu. Over 100,000 people died in that period, within both communities, especially the Hutu. In 1987, a new militant Hutu ultranationalist movement, PALI PEHUTU, carried out attacks on Tutsi, resulting in more reprisal killings. Despite considerable interethnic engagement in some political and communal settings, which had characterized Burundian society since the colonial period, increasingly racist political rhetoric, military insurgency, and inter-communal violence in the 1970s and 1980s helped set the stage for the "rolling genocides" 34 that occurred in Burundi throughout the 1990s.

In 1992, Burundi's first democratically elected Hutu head of state, Melchior Ndadaye, was assassinated, leading to reprisal and re-reprisal killings of tens of thousands of civilians. In 1994, Burundi's second Hutu president, Cyprien Ntaryamira, died with Rwandan President J uvénal Habyarimana, when their plane was shot down. This double assassination set off the genocide of nearly a million Tutsi and so-called

\footnotetext{
${ }^{34}$ The terms "volcanic genocide" and "rolling genocide" have been employed to contrast what might be called "short-term" or "long-term" genocides. See Madeleine K. Albright and William S. Cohen, Co-Chairs, Genocide Convention Task Force, Preventing Genocide: A Blueprint for U.S. Policymakers (United States Holocaust Memorial Museum, The American Academy of Diplomacy, and the Endowment of the United States Institute of Peace, 2008) at 57. While evocative, the difficulty with these terms is that they may suggest that some genocides are more "urgent" than others, when all genocides are criminal insofar as they involve acts intended to destroy human communities, in whole or in part.
} 
"moderate Hutus" in Rwanda in the space of 10 weeks, and the genocide of upwards of 300,000 Tutsi and Hutu in Burundi over the ensuing 10 years. ${ }^{35}$

In 1998, Pierre Buyoya, a Tutsi who became president in 1998 after seizing power in a coup in 1996, began peace negotiations with the Hutu-affiliated rebel movements, then composed of several groups, including the largest, CNDD-FDD. These negotiations - with important mediating roles played by former Presidents J ulius Nyerere of Tanzania, Nelson Mandela of South Africa, and Bill Clinton of the United States - led to the Arusha Accords, and, ultimately, to the 2003 election of Domitien Ndayizeye, who had been Buyoya's vice president, as the first post-war Hutu president of Burundi. That same year a cease-fire agreement was signed between the government and CNDDFDD. The FNL - the other major Hutu ultranationalist militant group, and the successor to PALI PEHUTU - was a hold-out.

In 2005, the former leader of CNDD-FDD, Pierre Nkurunziza, was elected president. In 2008, the FNL finally joined the Arusha Accords. In 2010, Nkurunziza was reelected after a campaign season characterized by pronounced intra-Hutu factionalism and marred by political killings widely attributed to CNDD-FDD and affiliated youth militias. For this reason, all the opposition candidates, including Agathon Rwasa, leader

\footnotetext{
${ }^{35}$ There are complex reasons behind the fact that the racialized killings of Tutsi and Hutu in Rwanda in 1994 are referred to as the "Rwandan Genocide" whereas the racialized killings of Tutsi and Hutu in Burundi from 1992 to 2003 are referred to as the "Burundian Civil War." The clear majority of victims in Rwanda in 1994 were Tutsi, whereas the victims were more equally represented across the two major ethnic communities in Burundi over its decade-long civil conflict. But this demographic difference alone does not explain the distinct ways of speaking of the repression and violence in the two countries, or the relative lack of awareness of the Burundian Civil War in the international public consciousness. The awareness gap regarding Burundi is partially explained by the complexity of Burundi's history and demographic makeup, its resistance to simplistic polarized ethnic and political characterizations, and the plain fact that Burundi's recent period of catastrophic violence was spread out over 10 years, rather than 10 weeks, as in Rwanda.
} 
of the FNL, and Alexis Sinduhije, leader of the Movement for Solidarity and Democracy (MSD), withdrew and boycotted the election. Political killings were pronounced for the next two years, and trials for individuals implicated in political violence have been marred by charges of due process violations. ${ }^{36}$

In 2013, Rwasa of the FNL and Sinduhije of the MSD both returned to Burundi, and in that same year, government and civil society representatives participated in a national conference on strengthening good governance and the rule of law. Nevertheless, charges of judicial and other forms of official corruption are ongoing. Political violence, including that attributed to CNDD-FDD-affiliated youth militias, continues. ${ }^{37}$ In this climate, transitional justice is a fragile, even perilous, project. To date, while Burundi's Arusha Accords called for both war crimes prosecutions and restorative justice, no war crimes tribunal has been established, and Burundi's Truth and Reconciliation Commission is just beginning its work.

Although the members of Burundi's TRC were not elected until December of 2014, Burundians have been engaged in historical memory projects for a decade, since the drafting of the Arusha Accords. Civil society organizations such as le Centre d'Alerte et Prévention de Conflit (CENAP) have called for local and national memorials, which are inclusive in their tribute to the victims of violence, and eloquent in their commitment to a trans-ethnic Burundian national identity. But the challenge of calling for national reconciliation without accountable political leadership and in a climate of

\footnotetext{
${ }^{36}$ See Human Rights Watch, World Report 2014, Burundi Chapter, available at http://www.hrw.org/worldreport/2014/country-chapters/burundi.

${ }^{37}$ Ibid.
} 
ongoing political violence is daunting to say the least. Burundian civil society engages in peacebuilding work in large part by demanding that the political leadership cease actively fomenting inter- and intra-ethnic competition and violence. Historicalreconciliative justice requires an end to such violence.

Finally, Burundian civil society is confronting the social dimension of transitional justice. Levels of poverty, hunger, youth unemployment, gender inequality, and violence against women have not significantly improved since the conclusion of Arusha Accords. Civil society organizations, including CENAP, continue to work for substantive political, legal, and social service reforms that will meaningfully address the physical and structural violence that continue to feed conflict in Burundi. The work of CENAP will be further explored in Section III below.

III. Gender and Class Inequality: Civil Society and the Unfinished Business of Transformational J ustice in Uganda, Sierra Leone and Burundi

Uganda's Refugee Law Project, Sierra Leone's Fambul Tok, and Burundi's Centre d'Alerte have been notable for their critiques of post-conflict transition in their respective countries and for their presentations of new approaches. The work of these organizations casts into relief some of the most serious impediments to transitional justice, which include structural as well as physical violence, and entrenched gender and class inequities. The gap between theorizing about the ideal elements of postconflict transition and implementing them is breathtakingly wide. This point is only strengthened when we examine the levels of human insecurity in all three countries, 
conditions that have not significantly improved since the end of full-scale armed conflict, and in some cases have worsened.

Entrenched Poverty: In order to reflect relative levels of material conditions of life internationally, statisticians of the United Nations Development Programme (UNDP), along with the World Bank and other organizations, have conceptualized and tabulated a so-called "human development index" (HDI), meant to serve as a comparative measure of the overall level of socioeconomic wellbeing in countries throughout the world. ${ }^{38}$ The basic gist of the HDI - as a measure of human security - is a composite numerical snapshot of three material conditions of life for people living in an individual country: (1) life expectancy; (2) years of education; and (3) GDP per capita. HDI scores are calculated out of a possible range of 0 to 1.0. The global mean HDI was .70 in 2013, and HDI scores for Uganda, Sierra Leone, and Burundi trended well below: .48 for Uganda, . 37 for Sierra Leone, and .39 for Burundi. ${ }^{39}$

The crushing reality behind these numbing statistics is that the level of human security has not significantly improved in Uganda, Sierra Leone, and Burundi since the end of full-blown military conflict several years ago.

Gender and Violence: In addition to the overall human welfare picture for Uganda, Sierra Leone and Burundi, the situation of women in each country bears special examination. In these and other "post-conflict" societies, the incidence of

\footnotetext{
${ }^{38}$ See, e.g., UNDP Human Development Report 2014, Sustaining Human Progress: Reducing Vulnerabilities and Building Resilience, Summary at 15-19, available at http://hdr.undp.org/en/content/human-development-report2014.

${ }^{39}$ UNDP Human Development Report 2014 at 18-19.
} 
gender-based violence tends to become more pronounced in the "post-conflict" period even as compared to the high levels of physical and other form of violence that prevailed during the war. As stated by Ní Aoláin, Haynes, and Cahn in their analysis of gender and transitional justice, "sexual and gender-based violence rarely conforms to the timelines of peace treaties and ceasefires but endures past them." ${ }^{\prime 40}$ The authors go on to cite the work of Meintjes, Pillay, and Turshen, whose research suggests that "there is a marked rise in the violence which women experience post-conflict." 41 Precise data is limited on levels of violence against women both during and after conflict. Further research needs to be done in the context of Uganda, Sierra Leone, and Burundi to be able to point to more concrete evidence of increased levels of violence in each country during the post-conflict period.

Given the lack of country-specific data, firm conclusions about the specific reasons for a post-conflict spike in gender-related violence is beyond the scope of this paper, ${ }^{42}$ but some initial concerns can be identified as points of departure for further study and action. One important aspect in analyzing gender-related violence is its scope. We are not merely speaking of sexual violence against women or even physical

\footnotetext{
${ }^{40}$ Fionnuala Ní Aoláin, Dina Francesca Haynes \& Naomi Cahn, On the Frontlines: Gender, War, and the PostConflict Process (Oxford University Press 2012) at 46.

${ }^{41}$ Ibid. at 47 and note 34 .

${ }^{42}$ Reliable statistics on levels of violence against women are difficult to obtain, for a variety of reasons, beginning with the difficulties in data collection, particularly during armed conflict, and the reality of under-reporting of incidents of violence, especially in the home, and given the shame that surrounds sexual violence. Nevertheless, as Ní Aoláin et al stress, women in conflict and post-conflict societies experience "a layering on of violence," the normalized forms of violence that reflect women's subservient status even in time of "peace" with the more "catastrophic" forms of violence associated with time of war. Ibid. at 46 . Their research and analysis suggests that while some of the "catastrophic" forms of violence may subside after the war, the overall normalization of violence endures, and violent conduct may even increase, particularly as male former combatants return to compromised post-war economies where "few other opportunities may be provided to gain economic security." Ibid. at 52.
} 
violence more generally. As asserted by Ní Aoláin et al, we should avoid "a fixation on harms to the body" ${ }^{\prime 3}$ and recognize that women are not only concerned about being raped, but also about their "inability to collect wood for stoves or to plant crops with the certainty of being able to harvest them." ${ }^{44}$ Structural violence - women's lack of access to birth control, pre and post-natal care, their inability to feed and provide clean water to themselves and their dependents, and their difficulty accessing educational and income-generating opportunities - is as important as physical violence to women in Uganda, Sierra Leone, and Burundi, as well as other societies emerging from armed conflict.

\section{Gender and Inequality:}

Linked to the incidence of violence against women in post-conflict societies is women's lower political and socio-economic status in those societies as compared to men and as compared to women in other parts of the world. Transitional justice proponents are beginning to focus on gender inequality and women's vulnerability for the sake of women themselves and in light of the crippling impact that women's subordination has on their families and communities. The connections between gender inequality and human insecurity in countries around the world are telling. In this vein, Ní Aoláin el al "maintain that there is a correlation between a state's security situation (its fragility) and its gender equity" and point to World Bank publications noting "that

\footnotetext{
${ }^{43}$ Ibid. at 41.

${ }^{44}$ Ibid. at 45.
} 
poverty rates tend to be lower in countries with more gender equality." ${ }^{45}$ Such studies strongly suggest that if women continue to be marginalized in post-conflict societies, their societies will remain weak as well.

As compared to specific measures of physical violence against women before, during, and after conflict, which are hard to come by, there is considerable genderdifferentiated data on other indicia of social wellbeing. The UNDP Human Development Report, by way of example, includes specific figures on gender inequality. ${ }^{46}$ The UNDP calculus takes into consideration five measures of women's life experience: (1) the maternal mortality rate, or the number of women who die when pregnant or in childbirth out of every 100,000 births; (2) the adolescent birth rate, or the number of births to teens between 15 and 19 years of age out of every 1000 mothers; (3) women's share of seats in the legislature; (4) the percentage of the population that attains high school, separated out for girls and boys; and (5) the percentage of the population participating in the work force, also gender differentiated. ${ }^{47}$ For our three country cases, the data are telling. Compared to the world at large, in Uganda, Sierra Leone, and Burundi many more women die in childbirth; more teens become mothers (except in Burundi); women fill proportionally more seats in Parliament than they do in other countries (except in Sierra Leone); fewer girls go to high school, especially relative to boys; and more women participate in the work force, with a narrower gender

\footnotetext{
${ }^{45} \mathrm{lbid}$. at 37 and notes 51 and 52, citing the World Bank, Global Monitoring Report 2010 and World Bank, Promoting Gender Equality and Women's Empowerment, in Global Monitoring Report 2007.

${ }^{46}$ See UNDP Human Development Report 2014, Table 4, Gender Inequality Index, at 172-79.

${ }^{47}$ Ibid.
} 
gap. The paragraphs below attempt to give more texture and precision to these broad characterizations. ${ }^{48}$

Maternal mortality is two to six times higher in post-conflict countries than in most other places in the world. On average globally in 2013, 145 women out of 100,000 expectant mothers died in pregnancy or childbirth. In Uganda, 310 died, for Sierra Leone the figure was 890, and in Burundi 800 women died out of 100,000.

Teen fertility rates are very high in most post-conflict countries. The global average in 2013 was 47.4 births to teen moms out of 1000 babies born. In Uganda, there were 126.6 births to teen moms out of 1000, in Sierra Leone the figure was 100.7, and in Burundi the figure was 30.3.

Women's proportionate representation in the legislature in some post-conflict countries is higher than the global average, which was $21.1 \%$ in 2013 . That same year, in Uganda women composed 35\% of all legislators, women in Sierra Leone were $12.4 \%$, and in Burundi women composed $34.9 \%$ of all legislators. Gender quotas account for some of these figures, reflecting national gender policies.

Young women enter secondary school in post-conflict countries at much lower rates than in the world at large, and the gap between girls and boys is more pronounced. Worldwide in $2013,54.2 \%$ of girls reached high school and $64.2 \%$ of boys. In Uganda, $22.9 \%$ of girls and $33.5 \%$ of boys entered high school; in Sierra Leone, $9.5 \%$ of girls and $20.5 \%$ of boys started secondary school; and in Burundi only $5.2 \%$ of girls and $9.3 \%$ of boys reached high school.

\footnotetext{
${ }^{48}$ The data analyzed in the next five paragraphs is also drawn from the UNDP Gender Inequality Index Chart, Table 4 of the UNDP Human Development Report 2014 (also cited in notes 45-46 above).
} 
Women's participation in the workforce in post-conflict countries is more pronounced than women's labor participation at the global level, the labor gender gap is narrower, and sometimes, perhaps not surprisingly, women work more than men. In 2013 globally, $50.6 \%$ of women participated in the work force, and $76.7 \%$ of men. That year in Uganda, $79.9 \%$ of women participated in the work force, a bit more than men, at $79.3 \%$. In Sierra Leone, $65.7 \%$ of women were in the labor force, close to men at $68.9 \%$. In Burundi, $83.2 \%$ of women participated in the labor market, just above men at $81.8 \%$.

Transitional / ustice and Structural Violence: In light of the quantitative and qualitative evidence, perhaps the most respectful and credible way to move forward with the work of transitional justice starts by acknowledging the harsh realities of entrenched poverty, violence, and gender inequality confronting societies emerging from armed conflict. Amid such conditions of human insecurity, civil society organizations are functioning, demanding accountability, seeking reconciliation, and enhancing social welfare in their respective countries. But much work remains to assess and support the role of such groups in addressing structural violence, and gender and other forms of inequality. In this spirit, the final passages of this paper present a modest beginning, by providing illustrative examples of current initiatives undertaken by organizations working in this hardscrabble environment, again spotlighting the three groups introduced in Section II.

A. The Refugee Law Project, Historical Memory, and Gender in Uganda 
In addition to their commitment to criminal accountability for past war crimes, Ugandan civil society organizations are also grappling with ongoing social tensions and structural violence in Northern Uganda. The Refugee Law Project has contributed to several initiatives which get at the need for deeper truth-telling about the past in order to strengthen communities at the local as well as national level in contemporary Uganda. In conjunction with the Faculty of Law of Makerere University and the Kitgum District Government, RLP established the National Memory and Peace Documentation Center in Kitgum, Northern Uganda. ${ }^{49}$ At the national and international level, RLP has also helped launch the work of the Institute for African Transitional J ustice, ${ }^{50}$ which sponsors residential workshops on transitional justice in the region.

On the social justice front, Northern Uganda is confronting high levels of human insecurity, despite the pacification of the LRA on Ugandan territory by around 2008. In addition to challenges in the labor sector, problems with health care delivery, limited educational and training opportunities, the Refugee Law Project recognizes the particular difficulties experienced by women in terms of insufficient psycho-social services for survivors of conflict-related violence, as well as the greater barriers to social support, which women face in the health, education, and employment sectors. In response to this web of social insecurity, the RLP has developed a Gender \& Sexuality Programme, which "works to ensure that all people access, recover and enjoy their

\footnotetext{
${ }^{49}$ Specific information about the [RLP] National Memory and Peace Documentation Center is linked to the webpage on "Conflict, Transitional Justice and Governance Programme," available at http://www.refugeelawproject.org/our-work/conflict,justice-and-governance.html.

${ }^{50}$ Information regarding the Institute for African Transitional Justice is available at http://www.refugeelawproject.org/iatj.html.
} 
sexual and gender being and rights, and to raise global awareness of the close relationship between violations of sexuality and gender, and patterns of forced migration."

B. Fambul Tok, Village-Level Reconciliation, and Gender in Sierra Leone Fambul Tok was founded in part to bring transitional justice to the grass-roots level, recognizing the important but limited impact of the Special Court and Sierra Leone's TRC on daily life and relationships in rural communities. As described in Section II above, Fambul Tok has developed a process of dialogue, preparation for reconciliation, and public cleansing rituals that has been utilized in kindred forms in other post-conflict countries and regions throughout the world. ${ }^{52}$

The Fambul Tok approach is not without its critics, particularly from a feminist perspective that remains skeptical of the long-term value of forgiveness ceremonies for women who remain in a subservient status within their communities. Ní Aoláin et al suggest that truth and reconciliation commissions in general may be problematic for women because "they are events which predominately seek to fold the experiences of the prior regime/conflict into a narrative that, from a gender perspective, has a consistent patriarchal undercurrent." ${ }^{53}$ Their concern with reconciliation "events" also applies to more intimate ceremonies in rural locales, because, for some women,

\footnotetext{
${ }^{51}$ Information regarding RLP's Gender \& Sexuality Programme is available at http://www.refugeelawproject.org/our-work/gender-and-sexuality.html.

52 See Moore, op. cit., at pp. 268-70 (re "Continuing the Work of Truth and Reconciliation at the Grassroots Level" and "Fambul Tok").

${ }^{53}$ Ní Aoláin et al, op. cit., at 183.
} 
speaking about the past may not have a cathartic and cleansing impact. They caution that it is "also important to understand the highly Westernized notions of agency represented by the speech act" ${ }^{54}$ and suggest a valuing of the "public silences [that] are a persistent feature of women's testimonial presentations in truth-telling contexts." ${ }^{\prime 55}$

Fambul Tok itself has attempted to consider the impact of public cleansing ceremonies on women. To address some of the particular ways in which women experience the process of public reconciliation, Fambul Tok has developed a program called the "Peace Mothers" which facilitates women-centered support groups in the communities in which cleansing ceremonies take place:

Thousands of women were raped or abused during the war, and they have largely born their burden in silence. Rape is a taboo subject in Sierra Leone, and many rape survivors are shunned. Yet at virtually all of the Fambul Tok bonfires, women come forward and tell the story of their sexual abuse and accuse their perpetrator, in public. That takes an extraordinary amount of bravery.

These conversations can also take a toll on women. To address their unique needs - not just the survivors of rape, but al/ women who have survived the war and its aftermath-the women of the villages have started support groups. They call themselves the Peace Mothers, and Fambul Tok walks with the women setting up these structures. Within these protective circles women are reclaiming their voices and their strength, and changing their lives and their society in new and wonderful ways. $^{56}$

\footnotetext{
${ }^{54} \mathrm{Ibid}$. at 184, citing Iris Marion Young, Inclusion and Democracy (2000).

${ }^{55} \mathrm{Ibid}$. at 184.

${ }^{56}$ See Fambul Tok, "How Fambul Tok Works: the Nuts and Bolts of the Fambul Tok Process," section on "FOLLOWUP ACTIVITES," sub-section on "Peace Mothers," available at http://www.fambultok.org/what-is-fambul-tok/ourprocess.
} 
It is indeed essential to ask women about the particular impacts that testifying publically about sexual violence have on them as survivors. At the same time, there may be some concern that cleansing ceremonies tend to focus on the violence that occurred in the past, to the exclusion of other forms of physical and structural violence and deprivation that women and their families continue to experience in the present and throughout the post-conflict period. This is not to say that Fambul Tok-style cleansing ceremonies cannot be empowering for women. Rather, organizations such as Fambul Tok will need to take a critical look at community-level reconciliation programs, continually retooling them to ensure that they have value for all members of communities emerging from violence.

\section{The Impact of Ebola}

Social justice in Sierra Leone cannot be discussed without acknowledging the crushing toll of the Ebola virus since mid-2014. ${ }^{57}$ By March 2015, over 8000 people had fallen sick, and over 3000 had died of the disease. ${ }^{58}$ The fragile health care system was hard hit as many health care workers became infected, particularly women, with similar impacts on education and industry. Sierra Leone's rate of economic growth, forecast at $11.3 \%$, was only $4 \%$ for $2014 .^{59}$ Ebola prevention and treatment and the rebuilding of

\footnotetext{
57 See Jennifer Moore, "The Responsibility to Protect in the Ebola outbreak," OUPblog, September 22, 2014, available at http://blog.oup.com/2014/09/responsibility-protect-r2p-west-africa-ebola-outbreak-pil/.

${ }^{58}$ UN Children's Fund, Sierra Leone Ebola Situation Report, March 4, 2015, available at http://reliefweb.int/report/sierra-leone/sierra-leone-ebola-situation-report-4-march-2015. .

59 World Bank, "The Economic Impact of Ebola on Sub-Saharan Africa: Updated Estimates for 2015," January 20, 2015, available at http://reliefweb.int/report/sierra-leone/economic-impact-ebola-sub-saharan-africa-updatedestimates-2015.
} 
the health care sector are paramount social justice issues for post-conflict transformation as Sierra Leoneans look to the future.

C. CENAP, Political Violence, and Structural Violence in Burundi

Burundi, with particular poignancy, raises the question of whether we may speak of post-conflict transition when high levels of political violence persist alongside the entrenched structural violence of poverty and inequality. Le Centre d'Alerte et Prévention de Conflit (CENAP) was founded in 2002 to engage in "conflict mitigation" and to promote national dialogue around peacebuilding and sustainable development. ${ }^{60}$ From 2007 to 2010, CENAP engaged in a multi-phased peacebuilding project, convening a series of local "town hall" meetings attended by broad sectors of Burundian society, including representatives of youth, women's and labor organizations, social service NGOs, former combatants, peace activists, academics, religious leaders, and government officials. In 2010, these meetings culminated in a national "big-tent" peacebuilding conference, at which the meaning of sustainable peace was discussed, Burundian-style. At its conclusion, participants articulated four priorities for peace consolidation in Burundi: political parties, and the management of victory and defeat; transitional justice, focused on historical memory and reconciliation; disarmament of the civilian population, and development of the security sector; and alleviating poverty and unemployment, particularly among youth. ${ }^{61}$

\footnotetext{
${ }^{60}$ Information in English about the work of CENAP is available at http://www.insightonconflict.org/conflicts/burundi/peacebuilding-organisations/cenap/.

${ }^{61}$ More information about CENAP's "Axes d'intervention" available at http://cenap.bi/index.php?option=com content\&view=article\&id=66\&ltemid=57.
} 
CENAP's work is ongoing, and its current approach to peacebuilding and postconflict transformation is worthy of further study and engagement. CENAP and other community-based organizations continue to explore all three dimensions of transitional justice, socio-economic, communal, and judicial. In addition to seeking reforms in the social sector, and taking steps to preserve historical memory and cultivate pan-ethnic solidarity, Burundian civil society continues to put pressure on the legal system, demanding reforms and calling for an end to the climate of impunity.

\section{Conclusion}

The experiences of Uganda, Sierra Leone, and Burundi illustrate that there is not one path to post-conflict transformation. Transitional justice must emerge from the particular cultural and historic landscape of a nation struggling with the legacy of war, cultivated by civil society. Community-based organizations like Refugee Law Project, Fambul Tok, and CENAP recognize the criminal, historical, and social strands of justice valuing individual accountability, restored relationships, and decent living conditions for all - yet they work in the face of fundamental constraints. Daunting impediments to post-conflict transformation include the flagrant politicization of criminal prosecutions, as in Uganda; the crushing reality of youth unemployment and disenfranchisement, particularly in Burundi; and the brittle intractability of gender inequality, as manifested in the persistent forms of physical and structural violence experienced by women and their dependents in all three countries.

Community-based agencies working in Uganda, Sierra Leone, and Burundi have no choice but to apply the rhetoric and rubrics of transitional justice in a dynamic 
process of trial and error, critique, and reformation. Their efforts help us to identify the unfinished business of post-conflict transformation, particularly in the areas of poverty alleviation and women's empowerment. Rising to these challenges, transitional justice may have greater meaning for people living in societies emerging from violence and repression, so that they may experience fuller measures of integrity, agency, and wellbeing in their daily lives. 